\title{
Influence of mineral fertilizers on potash nutrition and productivity of columnar apple
}

\author{
Larisa Leonteva* \\ Russian Research Institute of Fruit Crop Breeding (VNIISPK), Zhilina, Orel district, Orel region, \\ Russian Federation
}

\begin{abstract}
The columnar form of apple tree is promising for growing in super-intensive orchards. The mineral nutrition study of apple tree with columnar crown is relevant due to high density of tree planting. The article presents the study results on the effect of mineral fertilizers on potash nutrition and the yield of columnar apple tree. The experiments were carried out in an experimental orchard located in the forest-steppe zone of the Central Russian Upland (Oryol region). The soil of the orchard is loamy haplic Luvisol with a high content of organic matter. Fruit plantations are represented by columnar apple trees of Poezia variety on 62-396 rootstock planted in 2016. Urea $\left(\left(\mathrm{NH}_{2}\right)_{2} \mathrm{CO}\right)$ and potassium sulfate $\left(\mathrm{K}_{2} \mathrm{SO}_{4}\right)$ were used as fertilizers in doses of N60K80; N90K120; N120K160 which were introduced in early spring. The content of exchange potassium in the soil was determined annually in layers $(0-20 \mathrm{~cm}$ and $20-40 \mathrm{~cm})$, the concentration of potassium in leaves and fruits, yield. The use of fertilizers contributed to an increase in the exchange potassium content in the soil both in the $0-20 \mathrm{~cm}$ layer $(45-53 \%)$ and in the $20-40 \mathrm{~cm}$ layer $(18-31 \%)$. The amount of potassium in leaves and fruits also increased. However, potassium concentration in the leaves $(0.77 \ldots 0.95 \%$ dry matter $)$ remained significantly below the optimum (1.5\% dry matter). A significant increase in the average fruit weight was revealed in options N90K120 and N120K160.
\end{abstract}

\section{Introduction}

Mineral nutrition is an important factor in regulating the growth and fruiting of fruit trees, increasing yields and the basis for creating high-value products. Potassium is one of the main elements of plant's mineral nutrition and an indicator of soil fertility.

The role of potassium in plant life is versatile. This element helps to enhance the growth of trees, increase the fruits' size; increases winter resistance and cold tolerance, the activity of enzymes of carbohydrate metabolism (amylase and sucrose), enhances the action of proteolytic enzymes [1-3]. Plants provided with sufficient potassium have increased resistance not only to drought and cold, but also to infectious diseases $[4,5]$. This is one of the nutrients that are necessary for fruit plants at any period of development, especially during the fruiting period [6].

\footnotetext{
* Corresponding author: leonteva@vniispk.ru
} 
The study of potassium-containing fertilizers' interaction with soil was carried out by many researchers, but only a few works are devoted to the study of fruit crops' potassium nutrition. In addition, the data on the effectiveness of potassium applied with fertilization are often contradictory, since the work was carried out on soils with different properties and different research methods were used.

The columnar apple tree is one of the newer, most promising forms for super-intensive orchards. Columnar apple plants have several peculiarities: trees are compacts that form few lateral shoots with short internodes. Wood has increased strength, elasticity, and is able to withstand a large harvest [7]. [8].

Currently, there are only limited recommendations for fertilizing columnar apple trees

The aim of this work was to study the effect of mineral fertilizers on potash nutrition and the productivity of columnar apple tree.

\section{Materials and methods}

The research was carried out in a field experiment with columnar apple tree in the orchard area of the Russian Research Institute of Fruit Crop Breeding, (Oryol Region; $\left.53^{\circ} 00^{\prime} 09.5^{\prime \prime N} 36^{\circ} 04^{\prime} 19.1 " \mathrm{E}\right)$. The orchard was laid in 2016. Planting scheme - 4x1m. The experiment was carried out with columnar apple trees of 'Poezia' variety on a semi-dwarf rootstock 62-396. This variety has the following economically valuable traits: winter hardiness, early maturity, stable annual fruiting (due to the alternation of fruit spurs), scab resistance [9].

The soil of the experimental plot is loamy haplic Luvisol with a high content of organic matter. Agrochemical parameters in the $0-40 \mathrm{~cm}$ layer varied within the following limits: $\mathrm{pH}_{\mathrm{KCl}}$ - 4.81 - 4.69; humus - 4.61 - 3.81; labile $\mathrm{P}_{2} \mathrm{O}_{5}-152-116 \mathrm{mg} / \mathrm{kg}$, exchange $\mathrm{Ca}-14.98$ 15.59 m.e./100g, exchange $\mathrm{Mg}-4.39-4.5859$ m.e./100g. The soil maintenance system weedfree fallow.

The experiment started in 2017. Experimental options: 1. Control (without fertilizers); 2. $\mathrm{N}_{60} \mathrm{~K}_{80} ; 3 . \mathrm{N}_{90} \mathrm{~K}_{120} ; 4$. $\mathrm{N}_{120} \mathrm{~K}_{160}$.

The experimental repetition was 4-fold with 5 trees per each record plot. The arrangement of the options was systematic. Fertilizers were applied in the form of potassium sulfate $\left(\mathrm{K}_{2} \mathrm{SO}_{4}\right)$ and urea $\left(\left(\mathrm{NH}_{2}\right)_{2} \mathrm{CO}\right)$ annually in spring to a depth of $15 \mathrm{~cm}$.

Soil samples for analysis were taken annually at the end of the growing season at a distance of $0.3-0.5 \mathrm{~m}$ from the tree trunk separately from two layers - 0-20 cm and 20-40 $\mathrm{cm}$. The samples were dried at room temperature and grinded in a mill. Exchangeable potassium was extracted with $0.2 \mathrm{M} \mathrm{HCl}$ at a soil:solution ratio of 1:5.

Leaf samples were taken in the last ten days of July, fruit samples were taken in the phase of picking maturity. Plant samples were dried and ashed in an incinerator at a temperature of $450^{\circ} \mathrm{C}$. After incineration, the ash was dissolved in $20 \% \mathrm{HCl}$. The potassium content in the resulting solution was determined by flame photometry on a Sherwood flame photometer [10]. Accounting for the fruit yield was carried out by the weight method from each accounting tree.

The data obtained were processed by the method of one-way and two-way analysis of variance with an assessment of differences' significance based on Fisher's test and LSD at a significance level of $\mathrm{P}=0.05$ [11]. 


\section{Results and discussion}

The supply of the main nutrients from the soil to plants is greatly influenced by meteorological conditions. The growing seasons of the studied years did not differ significantly in air temperature from the average long-term data except for cooler May 2020 (picture 1).

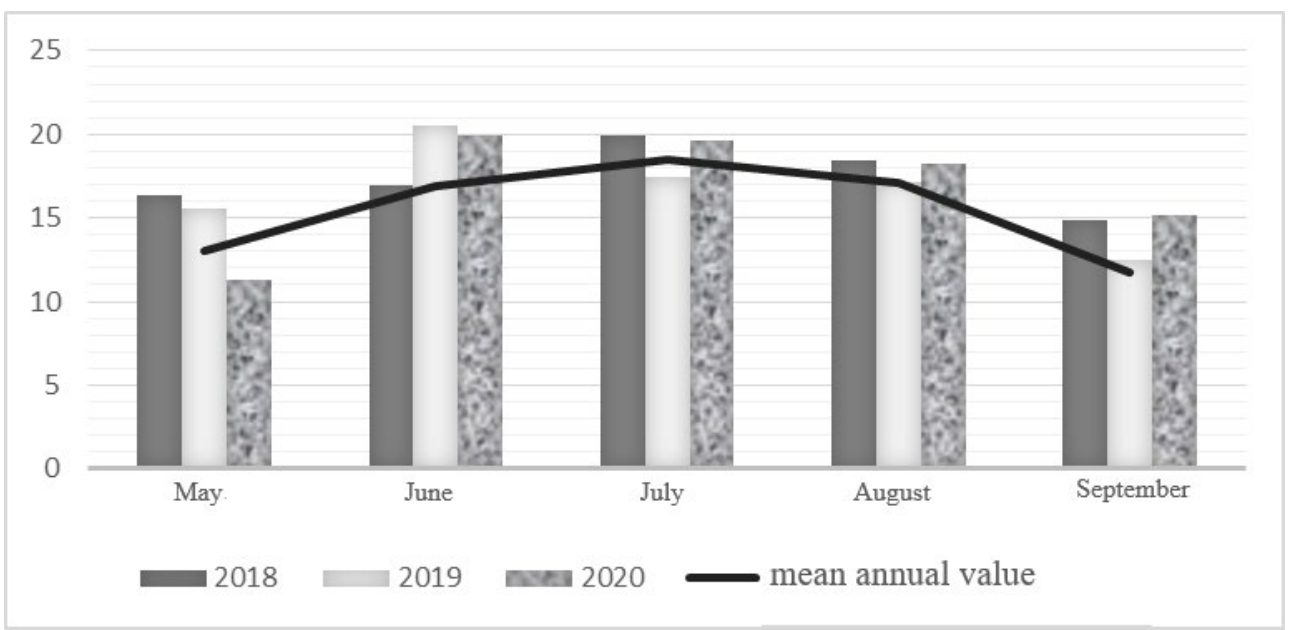

Fig. 1. Average monthly air temperature, ${ }^{\circ} \mathrm{C}$.

The amount of precipitation was different (table 1). In 2018 and 2020, large amount of precipitation fell in July, but June and August were dry. In 2019, the largest amount of precipitation fell in May, the rest of the months did not differ significantly from the average long-term data. However, in terms of precipitation amount over the growing season, all studied years were lower than the average long-term values, especially 2018.

Table 1. Amount of precipitation, $\mathrm{mm}$.

\begin{tabular}{|c|c|c|c|c|}
\hline \multirow{2}{*}{ Month } & \multicolumn{3}{|c|}{ Amount of precipitation } & \multirow{2}{*}{$\begin{array}{c}\text { Average mean } \\
\text { annual values }\end{array}$} \\
\cline { 2 - 4 } & 2018 & 2019 & 2020 & 36.4 \\
\hline May & 31.4 & 85.0 & 59.1 & 65.1 \\
\hline June & 18.2 & 20.7 & 46.4 & 88.0 \\
\hline July & 119.9 & 49.8 & 111.6 & 65.7 \\
\hline August & 11.2 & 54.7 & 26.0 & 43.2 \\
\hline September & 45.5 & 50.2 & 23.5 & 298.4 \\
\hline $\begin{array}{c}\text { Amount of } \\
\text { precipitation }\end{array}$ & 226.2 & 260.4 & 266.6 & \\
\hline
\end{tabular}

All fruit crops, including apple tree, are characterized by high potassium removal from the soil; therefore, it is important to monitor the K content dynamics [12]. The use of potash fertilizers is the most important source of this element's preservation in the soil. Almost all potash fertilizers used in agriculture are readily soluble in water. Their interaction with the soil occurs rather quickly, while the largest part of potassium is absorbed by exchange [13]. The content of exchange potassium in the soil is still the main indicator by which the level of plants' potassium nutrition is judged [14]. The good availability of this form of $\mathrm{K}$ is due to its ability to easily pass into a solution when exchanged with other cations, from which it is absorbed by plants. 
Table 2. The content of exchangeable potassium in the soil, $\mathrm{mg} / \mathrm{kg}$

\begin{tabular}{|c|c|c|c|c|}
\hline \multirow{2}{*}{$\begin{array}{ll}\begin{array}{l}\text { Factor } \\
\text { (experimental }\end{array} & \text { A } \\
\text { options) } & \end{array}$} & \multicolumn{3}{|c|}{ Factor B (years of research) } & \multirow{2}{*}{$\begin{array}{l}\text { Average for } \\
\text { factor A }\end{array}$} \\
\hline & 2018 & 2019 & 2020 & \\
\hline \multicolumn{5}{|c|}{ layer $0-20 \mathrm{~cm}$} \\
\hline Control & 96.33 & 108.97 & 100.05 & 101.78 \\
\hline N60K80 & $124.85 *$ & $144.32^{*}$ & $140.61^{*}$ & 136.59 \\
\hline N90K120 & $155.96^{*}$ & 194.03* & $169.82 *$ & 173.27 \\
\hline N120K160 & $184.19^{*}$ & $191.59^{*}$ & $201.51^{*}$ & 192.43 \\
\hline $\begin{array}{l}\text { Average for factor } \\
\text { B }\end{array}$ & 140.33 & 159.73 & 152.99 & \\
\hline \multicolumn{5}{|c|}{ LSD05 $\mathrm{A}=19.23 \mathrm{LSD} 05 \mathrm{~B}=16.65 \mathrm{LSD} 05 \mathrm{AB}=33.30$} \\
\hline \multicolumn{5}{|c|}{ layer $20-40 \mathrm{~cm}$} \\
\hline Control & 69.67 & 67.73 & 58.92 & 65.44 \\
\hline N60K80 & 77.42 & $87.92 *$ & 65.32 & 76.89 \\
\hline N90K120 & $90.28^{*}$ & $100.28^{*}$ & $78.39 *$ & 89.65 \\
\hline $\mathrm{N} 120 \mathrm{~K} 160$ & $93.79 *$ & $99.23 *$ & $91.33^{*}$ & 94.78 \\
\hline $\begin{array}{l}\text { Average for factor } \\
\text { B }\end{array}$ & 82.79 & 88.79 & 73.49 & \\
\hline \multicolumn{5}{|c|}{ LSD05 $\mathrm{A}=17.48 \mathrm{LSD} 05 \mathrm{~B}=15.13 \mathrm{LSD} 05 \mathrm{AB}=30.27$} \\
\hline
\end{tabular}

* differences with control are significant at $5 \%$ significance level.

In the control experimental option, the concentration of $\mathrm{K}_{2} \mathrm{O}$ varied within $96.33 \ldots 108.97$ $\mathrm{mg} / \mathrm{kg}$ of soil, which corresponds to a low $(<100 \mathrm{mg} / \mathrm{kg})$ and medium $(100-180 \mathrm{mg} / \mathrm{kg})$ level for fruit crops [15].

The results of a three-year study showed a significant increase in the content of exchange potassium in options with the use of fertilizers in a layer of $0-20 \mathrm{~cm}$ from medium to high $(>180 \mathrm{mg} / \mathrm{kg})$. A high level of $\mathrm{K}_{2} \mathrm{O}$ content was achieved in the second year (2018) after the experiment's start in the option with the highest dose. In 2018 and 2020, the increase in $\mathrm{K}_{2} \mathrm{O}$ concentration is directly proportional to the applied dose of fertilizers. In 2019, no significant differences were found between the doses of $\mathrm{K}_{120}$ and $\mathrm{K}_{160}$.

A relationship is often noted between the distribution of potassium in fertilizers along the soil profile and the granulometric composition of soils [16]. So, on loamy soils, which are characteristic of the used experimental site, potassium can migrate along the soil profile up to $60 \mathrm{~cm}$. Potassium fertilizers led to an increase in the available potassium content both in the $0-20 \mathrm{~cm}$ layer (45-53\% on average over three years) and in the $20-40 \mathrm{~cm}$ layer (18$31 \%$ ), which is consistent with the data of other researchers [17].

Leaf analysis data are often used to assess the nutritional status of apple plants [18]. For leaf diagnostics, mature, fully formed, but still actively functioning leaves are required. Columnar varieties, in comparison with varieties that do not have a columnar habit, are characterized by a higher saturation of the crown with leaf surface.

The concentration of potassium in the leaves depends on various factors, including the element's availability in the soil; weather conditions (lack of precipitation and high temperatures can reduce the potassium content). A significant influence on the K content in the leaves is exerted by the crop load. Due to the high mobility and the urgent need during the ripening period, potassium from the leaves partially passes into the fruits.

Data on the content of potassium in leaves are presented in table 3.

Table 3. The content of potassium in the leaves of columnar apple, $\%$ dry matter

\begin{tabular}{|l|c|c|c|c|}
\hline \multirow{2}{*}{$\begin{array}{l}\text { Factor A } \\
\text { (experimental options) }\end{array}$} & \multicolumn{3}{|c|}{ Factor B (years of research) } & $\begin{array}{l}\text { Average for } \\
\text { factor A }\end{array}$ \\
\hline Control & 2018 & 2019 & 2020 & 0.77 \\
\hline N60K80 & 0.96 & 0.68 & 0.67 & 0.85 \\
\hline
\end{tabular}




\begin{tabular}{|l|c|c|c|c|}
\hline N90K120 & 0.98 & $0.88^{*}$ & $0.84^{*}$ & 0.90 \\
\hline N120K160 & 1.02 & $0.93^{*}$ & $0.89^{*}$ & 0.95 \\
\hline Average for factor B & 0.99 & 0.82 & 0.79 & \\
\hline \multicolumn{4}{|c|}{ LSD05 A =0.08 LSD05 B = 0.07 LSD05 AB =0.13 } \\
\hline
\end{tabular}

* differences with control are significant at $5 \%$ significance level.

The largest amount of potassium in the leaves was contained in 2018, when the fruits on the trees were single. The difference between the options was within the experimental error. In subsequent years, significant differences between the options were noted; however, the potassium content decreased compared to 2018 , which was probably associated with an increasing crop load, high mobility of potassium and its transport to fruits.

The optimal amount of $\mathrm{K}$ in the leaves of columnar apple varies from 1.2 to $1.8 \%$ dry matter [19]. Despite that the amount of potassium in the soil in the options with fertilizers rises to a high level, its amount in the leaves remains below optimal. The low K content can be associated both with an increasing crop load and with high soil saturation with exchange compounds of calcium and magnesium, which hinder the entry of potassium into plant roots [20].

The content of potassium in the apples is higher than that of other elements, therefore, it is most of all removed from the soil with the fruits. The maximum need for this element arises when the fruits grow and ripen [21].

The effect of $\mathrm{K}$ on fruit quality can be explained by that this element improves photosynthetic activity, as well as the translocation of metabolites from leaves to fruits [22].

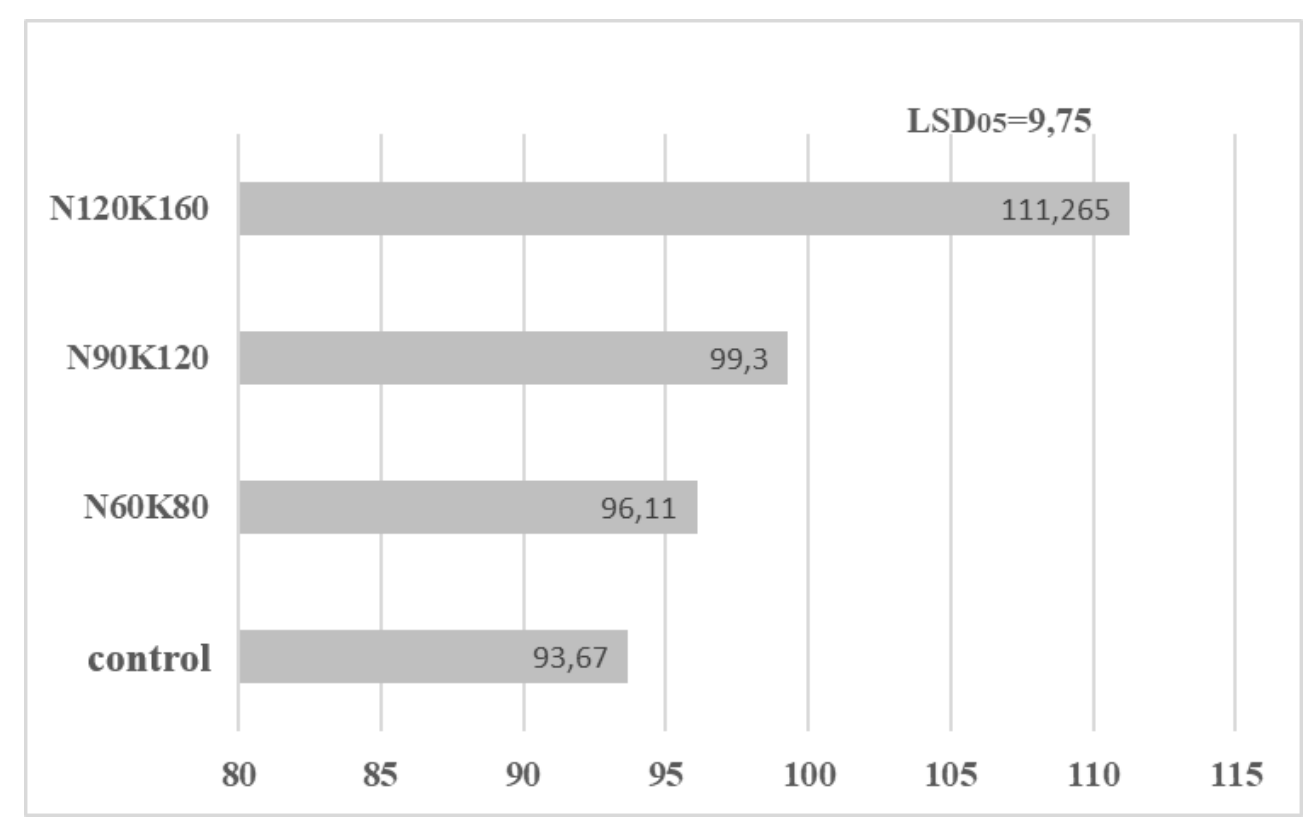

Fig. 2. The content of potassium in columnar apple fruits, mg / $100 \mathrm{~g}$ raw weight.

The potassium content in fruits increases in options with mineral fertilizers, but the amount of K significantly exceeds the control only in N120K160 option.

The first marketable crop was obtained in 2020. In the options with the use of mineral fertilizers, the yield was higher than in the control, however, the difference between the options was within the experimental error.

Potassium plays an important role in obtaining good quality fruits [23, 24]. One of the main indicators of marketability is the average fruit weight, which is usually considered a 
varietal trait. However, this indicator may change under the influence of many factors: soil conditions, meteorological conditions, yield values, etc. Data analysis allows to conclude that the use of mineral fertilizers in doses of N90K120 and N120K160 contributes to a significant increase in the average weight of fruits relative to the control.

Table 4. Influence of mineral fertilizers on yield and average fruit weight.

\begin{tabular}{|c|c|c|}
\hline Option & Yield, $\mathrm{kg} /$ tree & Average fruit weight, $\mathrm{g}$ \\
\hline control & 2.66 & 129 \\
\hline N60K80 & 3.32 & 141 \\
\hline N90K120 & 3.00 & $155^{*}$ \\
\hline N120K160 & 3.64 & $150^{*}$ \\
\hline LSD05 & $\mathrm{Ff}<\mathrm{Ft}$ & 20 \\
\hline
\end{tabular}

* differences with control are significant at $5 \%$ significance level.

\section{Conclusions}

As a result of the studies carried out, it was found that the annual application of potassium fertilizers in the form of $\mathrm{K}_{2} \mathrm{SO}_{4}$ to the haplic luvisol soil during the cultivation of columnar apple promoted an increase in the content of exchange potassium both in the 0-20 cm layer and in the 20-40 cm layer. An increase in the content of exchange potassium in the soil led to an increase in the concentration of this element in leaves (by $23 \%$ on average over three years) and fruits (by 18\%) but did not allow reaching the optimal level of content in the leaves.

In 2020, the first marketable crop was obtained. The differences between the options were within the experimental error. However, it is too early to draw conclusions regarding the effect of mineral fertilizers on the yield after one year of obtaining results; further study is required. A significant increase in the average fruit weight was revealed in options N90K120 and N120K160.

\section{References}

1. A. A. Zyalalov, M. Sh. Sibgatullina, A. I. Barieva, V. A. Plekhanova, Agrochemistry 1, 27-32 (2010)

2. G. H. Rather, S. K.Bansal, O. Bashir, U.Waida, Indian Journal of Fertilizers 15(7), 790797 (2019)

3. X. Xu, X.Du, F. Wang, J. Sha, Q. Chen, G. Tian, Frontiers in Plant Science 11, 904 (2020)

4. A.K. Kondakov, Fertilizing Fruit Trees, Berry-Fields, Nurseries and Flower Crops, 327 (2007)

5. T. Bruulsema, C.DiFonzo, C.Gratton, Better crops with Plant Food 94(2), 11-13 (2010)

6. L.V. Grigoreva, E.V. Gorlova, V.N. Makarov, Bulletin of Michurinsk State Agrarian University 4(59), 13 - 16 (2019)

7. E.N. Sedov, Z.N. Serova, S.A. Korneeva, Contemporary horticulture 3(11), 1-8 (2014)

8. S.N. Konovalov, Fruit Growing and Viticulture of South Russia 11, 56-67 (2011)

9. S. A Korneeva, E. N Sedov, T. V Yanchuk, E3S Web of Conferences 254, 01004 (2021) FARBA 2021 https://doi.org/10.1051/e3sconf/202125401004 
10. V.G. Mineev, V.G. Sychev, O.A. Amelyanchik, T.N. Bolsheva, N.F. Gomonova, E.P. Durynina, V.S. Egorov, E.V. Egorova, N.L. Edemskaya, E.A. Karpova, et al. Educational Aid on Agricultural Chemistry, 689(2001)

11. B.A. Dospehov A Field Experiment Method, 351 (1985)

12. N.A. Kodochilova, V.S. Komissarova, Bulletin of Ulyanovsk State Agricultural Academy, 1(45), 45-51 (2019) DOI: 10.18286/1816-4501-2019-1-45-51

13. L.V. Yakovleva, V.A. Polyakov, S.S. Zhdanov, Vladimir agricolist., 4, 14-20 (2018) DOI:10.24411/2225-2584-2018-10034

14. V.N. Yakimenko, The Journal of Soils and Environment, 1(1), 25-31 (2018) DOI: $10.31251 /$ pos.v1i1.5

15. A.K. Kondakov, Fertilizing of fruit trees, berry plants, nurseries and ornamental crops, 327 (2007)

16. V.N. Yakimenko Agrochemistry, 3, 5-11 (2007)

17. A. Szewczuk, A. Komosa, E. Gudarowska Acta Sci. Pol., HortorumCultus., 10(1), 83$94(2011)$

18. G.R. Nachtigall, A.R. Dechen, Scientia Agricola., 63(5), 493-501 (2006)

19. M.V. Kachalkin, Pomiculture and Small Fruits Culture in Russia, 10, 310-316 (2003)

20. E.V. Leonicheva, T.A. Roeva, L.I. Leontieva, O.A. Vetrova, M.E. Stolyarov, Contemporary Horticulture

URL:http://journal.vniispk.ru/pdf/2016/4/47.pdf

(2016)

21. A. I. Kuzin, N. Y. Kashirskaya, A. M. Kochkina, A. V. Kushner, Plants 9(10), 1366 (2020)

22. G. Raghavendra, S.I. Athani, S.N. Patil, Y.K. Kotikal, T.B. Allolli, A Alur Ann. Agric. Res. New Series 39(3), 277-280 (2018)

23. J. M. Rabelo, M.C.M. da Cruz, C. G. Sena, L. de Araújo Pantoja, A. S. dos Santos, L. A. C. Reis, \& A. G Guimarães, Emirates Journal of Food and Agriculture, 658-665 (2020)

24. G. Y. Wang, X. Z. Zhang, W. A. N. G. Yi, X. F. Xu \& Z. H. Han Journal of Integrative Agriculture 14(5), 864-874 (2015) 